\title{
Metaphor-based calques in Croatian mass media
}

\author{
Goran Schmidt \& Ivana Marinić \\ University of Osijek
}

\begin{abstract}
Readers of Croatian daily newspapers and news websites are very frequently faced with Croatian phrases which have been modelled on English templates by literal, word-for-word translation, a phenomenon known as CALQUE. This research shows that even highly proficient Croatian speakers of English as a second language (L2) are sometimes not able to fully understand the calques used in Croatian mass media unless they are familiar with the meaning of their source template in English. The research is done by way of an experiment built in PsychoPy (Pierce, 2007). The implications of this research could be of special interest to persons involved in designing media texts, professional and student translators, as well as to mass media consumers.
\end{abstract}

Keywords: calque; metaphor; comprehension; Croatian; English; mass media.

\section{Introduction}

Readers of Croatian daily newspapers and news websites are very frequently faced with Croatian phrases which have been modelled on English templates by literal, word-for-word translation, a phenomenon known as CALQUES. This research focuses on one particular type of calques, namely those that are modelled on metaphor-based noun-plus-noun English compounds (e.g. Eng: rat race, Cro: utrka štakora). Since metaphors are often specific to a culture or language, we wonder what happens when such expressions are translated more or less literally into another language, i.e. how this affects comprehension.

Calques are generally described as a type of linguistic BORROWING, more particularly COVERT borrowings or reproductions of a source language $(=S L)$ template using the inventory of target language elements, as defined in Turk (2013: 45). Haspelmath \& Tadmor (2009: 39) define calques as complex lexical units that were created by an item-by-item translation of the (complex) source units, and see them as an important type of structural borrowing. Pavlović (2015: 75) similarly states that literal translation or calque encompasses procedures whereby a culturally specific expression is literally translated, with a certain degree of adaptation to the 
target language. According to Turk (2013: 166) the function of calques is to fill empty lexical fields, which would explain the great amount of calques in many languages influenced by English. However, the situation is not that simple. Haspelmath \& Tadmor (2009: 46), for example, claim that the borrowing process is not really necessary and that in all languages it is possible to create new words for new concepts. Furthermore, they categorize loanwords into three categories on the basis of the effect they have on the lexical stock of the recipient language: insertion (the loanword is a completely new item), replacement (the loanword replaces a word with the same meaning), or coexistence (the loanword coexists with a native word).

With time, certain calques become institutionalized, in the sense of "the integration of a lexical item, with a particular form and meaning, into the existing stock of words as a generally acceptable and current lexeme" (Quirk et al, 1985: 1522 ff.). Pavlović (2015: 92) points to the fact that although literal translation of a phraseological unit is in most cases considered a sign of a lack of translator's competence, this kind of procedure has nevertheless been used throughout the whole history of translation. Also, she adds, a large number of phraseological units, which are today considered linguistic wealth, have entered the language precisely in that way. Interestingly, calques may become institutionalized with a meaning that is different than the meaning of the SL template. If the template is based on a culturallyspecific metaphor, there is a chance that the calque will undergo a semantic shift away from its template (Marinić, 2015). We are in agreement with Pavlović (2015: 75f), who, following Ivir, concludes that literal translation is not an adequate solution if it results in a syntagm with a completely different meaning than the original syntagm. Reasons why some loanwords have been accepted whereas other are treated as 'bad language' are historical, social and cultural (see Haspelmath \& Tadmor, 2009: 46-51), and are not in the focus of this research. The use of calques is quite common in Croatian online media where texts from English are translated on a daily basis, very often by not particularly specialized translators. When the calques are based on English metaphorical noun compounds, the question arises whether readers of these texts can understand their meaning. For example, the English noun-noun compound rat race is used to describe the exhausting and repetitive lifestyle in which work is seen as endless pursuit with little reward or purpose. In Croatian, it is often translated as utrka štakora, which in our opinion does not say much to Croatian native speakers.

In other words, when it comes to the comprehension of multiword calques, especially metaphorical and recent ones, it is fair to assume that without an explanation of their meaning or a very clear context it would be impossible or rather difficult to unpack their meaning. When speakers combine (two) words in a language, their individual meanings (and underlying cognitive structures) do not just add up; rather, certain elements of their underlying conceptual structure project into a blend (during which many complex cognitive phenomena might be at work) with 
a new, very often unexpected meaning (Fauconnier \& Turner, 1998, 2002; Turner \& Fauconnier 1995, 2000; Coulson \& Oakley, 2000; Turner, 2007). On the other hand, when trying to understand an unknown linguistic unit (in this case a two-word calque), we rely on our previous knowledge, experiences, roles, beliefs - in other words semantic frames as defined by Fillmore (1982: 111). If, however, certain knowledge is missing or is not profiled in the Langackerian sense (Langacker, 1987: 183), the interpretation of the calque will differ from its meaning in the source language.

Although calques are a frequent phenomenon in Croatian, there has not been much research on the comprehension of calques, i.e. the public is being 'served' some new expressions in spite of the fact that little is known about whether people are capable to understand them. According to Turk (2013: 329-332) comprehension of calques may be influenced by speaker's age, professional competence, experience, interests; by their usage frequency and recentness, whereas knowledge of the foreign language (on which the calque is based) is of no direct help in the semantic interpretation of calques (Turk, 2003). This is to be taken cautiously, as Pavičić Takač et al. (2015: 54) suggest, because this might mean that Turk's conclusion refers to the knowledge of individual lexical items which does not guarantee the successful interpretation of phraseological units of which these lexemes are part. This is a claim that we would agree with, especially in case of phraseological calques, often based on culturally specific metaphors. Thus, even if we can guess that ljubavni štakor (Cr.) is modelled on love rat (En.), it does not automatically make us understand its meaning in spite of the fact that we know the meaning of love and rat as individual lexical items. The study by Pavičić Takač et al. (2015) deals with the reception and production of a sample of replications (this is a term they adopted instead of the traditional term borrowing) of English patterns and matter attested in Croatian online news sources in native speakers of Croatian. The study covers a wide scope of replications: lexical items, collocations, phraseological units and syntactic patterns. A number of variables were examined to see whether they influence recognition, comprehension and usage of borrowings: knowledge of English as a second language (=L2), length of English language study, context, age, and online news reading habits. Pavičić Takač et al. (2015) came to the conclusion that knowledge of English plays a central role and that age, length of English language study and online news reading habits were significant factors in all subsamples but in the subsample 'Students of English'. They also found that the role of context is generally facilitating, but in some cases it seemed to have sidetracked the informants. The third study of the comprehension of calques by native speakers of Croatian (Marinić \& Schmidt, 2017) examined four factors that potentially influence the comprehension of metaphor-based phraseological calques: usage frequency, recentness, context, and the English language proficiency. No meaningful correlation was found between usage frequency and comprehension, nor between recentness and comprehension. A positive correla- 
tion was found between context and comprehension, as well as between the English language proficiency and comprehension. Thus, the study shows that the right context and a proficiency in English were helpful for the comprehension of certain phraseological calques. However, a number of items were not correctly interpreted, which points to the fact that context and knowledge of the source language are sometimes not sufficient for comprehension. Marinić \& Schmidt (ibid.) conclude that there must be another factor at play in the comprehension of such items. They set up a new hypothesis which states that in order to fully comprehend certain phraseological calques one has to know the conventional meaning of the SL template. This particular hypothesis is tested in the present study.

\section{Research and methodology}

\subsection{The hypothesis}

As shown in Marinić \& Schmidt (ibid.), when it comes to the comprehension of metaphor-based phraseological calques derived from English templates, English language proficiency (as L2) and context have proved to be helpful. However, some items were not correctly interpreted even when they appeared within context and when the participants' English language proficiency was rather high. This fact led to the assumption that in order to fully comprehend certain phraseological calques one has to know the conventional meaning of the SL template. Admittedly, knowing the conventional meaning of the English template is also a part of English language proficiency; however, it is a very specific part, especially when fairly recent or less known expressions are considered. Therefore we take the 'knowledge of recent English phraseological expressions' as a separate variable, distinguishing it from 'English language proficiency', as a general kind of knowledge and skill. The hypothesis that we test may be formulated in the following way:

Knowledge of the conventional meaning of the English template will increase comprehension of the Croatian calque based on that template.

In other words, even highly proficient speakers of English as a second language will not be able to fully understand the calque ljubavni štakor unless they are familiar with the meaning of its source template love rat in English.

In order to test the above hypothesis, we set out to see whether there is a difference in comprehension of metaphor-based phraseological calques based on English templates in speakers who are familiar with the particular English expressions vs. speakers who are not familiar with these expressions. The tested groups were similar to those used in the previous research to make sure that the variable 'English language proficiency (as L2)' is not changed and to be able to compare research results. 


\subsection{Database}

Noun-noun compounds, collected from various sources (Urban Dictionary 19962016; Benczes, 2006; COCA "the Corpus of Contemporary American English" (Davies, 2008-)), served as a starting point for research. Namely, according to Biber et al (1999: 589) nouns are the second most common noun premodifier in all registers, especially in journalist register. In Croatian, on the other hand, this structure is not that common. Since in Croatian online media there is an increasing number of texts translated from English originals, it is reasonable to assume that these structures posed problems for translators and we wondered what kinds of solutions were offered. Among many possible English templates, ten examples were selected which were translated literally into Croatian without any explanation of their original meaning in English (e.g. one of the test items is majka tigrica, which is a calque based on the template tiger mother). The main criterion for the selection of Croatian test examples was that the calque appeared at least occasionally in the "Croatian National Corpus" HNK (Tadić, 2009) and/or popular web news portals (jutarnji.hr, vecernji.hr, zarez.hr, etc.), but did not appear in Croatian dictionaries, ${ }^{1}$ which indicates that these calques are being used in Croatian public discourse, but have not yet been institutionalized in the sense of Quirk et al. (1985: 1522). It must be added that three of the English noun-noun compounds which served as templates for the Croatian calques used in the experiment (monkey business, eye opener, and rat race) were found in English-Croatian bilingual dictionaries (Filipović, 1999; Bujas, 1999); however, the dictionaries did not offer their Croatian equivalents, but rather described / paraphrased their meaning. Table 1 lists the 10 selected English compounds, their meaning, and the Croatian calques based on them as found on Google and in the HNK. ${ }^{2}$ All of the selected English compounds are culturespecific items (as defined by Aixelá, 1996), ${ }^{3}$ which are in Croatian lexicalized by LOAN TRANSLATION (phraseological calques). Croatian calques based on the selected English compounds do not necessarily retain the noun + noun form, except for: majka tigrica 'tiger mother' and party životinja 'party animal' (see Table 2). In line with Langacker's (1987:58) notion of SYMBOLIC UNITS which are conventional pairings of form and meaning, the elements of Croatian calques have the same (MODIFIER + HEAD) relationship. However, this relationship is not taken as a variable in this study and therefore it is not further analysed.

\footnotetext{
${ }^{1}$ We checked Anić (2004), which is the most comprehensive dictionary of contemporary Croatian, and $\mathrm{HJP}$, a 116.516 word online dictionary database, which comprises several Croatian dictionaries. Of the 10 selected examples, only majmunska posla 'monkey business' appears in the HJP, under the entry majmunski 'adjective referring to monkey', but not as an individual entry.

2 Garažno vino 'garage wine' and ljubavni štakor 'love rat' were found on Google only, and did not appear in the HNK.

${ }^{3}$ Aixelá (1996: 57-58) defines culture-specific items as either not existing in the target language culture or having a different value (whether determined by ideology, usage, frequency, opacity, acceptability etc.).
} 
Table 1. English metaphorical N+N compounds and the Croatian calques modelled after them

\begin{tabular}{|c|c|c|}
\hline $\begin{array}{l}\text { English } \\
\text { noun + noun } \\
\text { compound }\end{array}$ & Meaning a & $\begin{array}{l}\text { Croatian } \\
\text { calque }\end{array}$ \\
\hline garage wine & $\begin{array}{l}\text { Wines that come from previously unknown estates without } \\
\text { proven track record or pedigree; The wines produced by } \\
\text { these estates often receive very high wine ratings and are } \\
\text { usually sold at high prices ("Garagistes", 2015). }\end{array}$ & $\begin{array}{l}\text { garažno } \\
\text { vino }\end{array}$ \\
\hline $\begin{array}{l}\text { monkey } \\
\text { business }\end{array}$ & Mischievous or deceitful behaviour. & $\begin{array}{l}\text { majmunska } \\
\text { posla }\end{array}$ \\
\hline love rat & A man who is sexually unfaithful or promiscuous. & $\begin{array}{l}\text { ljubavni } \\
\text { štakor }\end{array}$ \\
\hline $\begin{array}{l}\text { business } \\
\text { angel }\end{array}$ & $\begin{array}{l}\text { A person who supports a business financially, typically one } \\
\text { who invests private capital in a small or newly established } \\
\text { enterprise. }\end{array}$ & $\begin{array}{l}\text { poslowni } \\
\text { anđeo }\end{array}$ \\
\hline snail mail & The ordinary postal system as opposed to e-mail. & $\begin{array}{l}\text { puževa } \\
\text { pošta }\end{array}$ \\
\hline glass ceiling & $\begin{array}{l}\text { An unacknowledged barrier to advancement in a profession, } \\
\text { especially affecting women and members of minorities. }\end{array}$ & $\begin{array}{l}\text { stakleni } \\
\text { strop }\end{array}$ \\
\hline tiger mother & $\begin{array}{l}\text { A strict or demanding mother who pushes her children to } \\
\text { high levels of achievement, using methods regarded as typi- } \\
\text { cal of childrearing in China and other parts of East Asia. }\end{array}$ & $\begin{array}{l}\text { majka tigri- } \\
\text { ca }\end{array}$ \\
\hline party animal & $\begin{array}{l}\text { A very gregarious and outgoing person who enjoys parties } \\
\text { and similar social activities. }\end{array}$ & $\begin{array}{l}\text { party život- } \\
\text { inja }\end{array}$ \\
\hline eye opener & $\begin{array}{l}\text { An event or situation that proves to be unexpectedly enlight- } \\
\text { ening; (North American) An alcoholic drink taken early in } \\
\text { the day. }\end{array}$ & $\begin{array}{l}\text { otvarač } \\
\text { očiju }\end{array}$ \\
\hline rat race & $\begin{array}{l}\text { A way of life in which people are caught up in a fiercely } \\
\text { competitive struggle for wealth or power. }\end{array}$ & $\begin{array}{l}\text { utrka štako- } \\
\text { ra }\end{array}$ \\
\hline
\end{tabular}

a All the definitions (except for garage wine) are taken from OxfordDictionaries.com (2016).

Table 2. Selected English N+N compounds, Croatian calques, and form of Croatian calques

\begin{tabular}{lll}
\hline English N+N compound & Croatian calque & Croatian calque form \\
\hline garage wine & garažno vino & adjective + noun \\
monkey business & majmunska posla & \\
love rat & ljubavni štakor & \\
business angel & poslovni anđeo & \\
snail mail & staklena pošta & \\
glass ceiling & majka tigrica & $\begin{array}{l}\text { noun + noun (reversed order } \\
\text { of constituents for majka } \\
\text { tiger mother }\end{array}$ \\
party animatica)
\end{tabular}




\begin{tabular}{lll}
\hline $\begin{array}{l}\text { eye opener } \\
\text { rat race }\end{array}$ & $\begin{array}{l}\text { otvarač očiju } \\
\text { utrka štakora }\end{array}$ & $\begin{array}{l}\text { noun + genitive noun (re- } \\
\text { versed order of constituents } \\
\text { in both cases) }\end{array}$ \\
\hline
\end{tabular}

To test how often the selected Croatian calques appear in online sources, we used Google and HNK search. Apparently, the target Croatian calques appear with various frequencies (Table 3). The number of Google hits is to be taken with caution, because it often lists the same web pages as different results, and it is quite impossible to control what particular results actually refer to, especially those where non-metaphorical meanings are possible as well. The Croatian National Corpus (HNK) is a collection of selected texts written in contemporary Croatian covering different media, genres, styles, fields and topics. As Table 3 shows, two items were not found in the HNK and most of the others appear very infrequently ( 3 to 116 hits per 101.3 million words). The figures indicate that the target items are rare in Croatian public discourse and therefore most probably unfamiliar to Croatian speakers, especially to those who did not learn them as a part of their English language education.

Table 3. Frequency of selected Croatian calques (Google and HNK)

\begin{tabular}{lcc}
\hline \multicolumn{1}{l}{ Target item } & number of Google hits & number of hits in HNK \\
\hline $\begin{array}{l}\text { stakleni strop } \\
\text { 'glass ceiling' }\end{array}$ & 4470 & 116 \\
\hline $\begin{array}{l}\text { poslovni anđeo } \\
\text { 'business angel' }\end{array}$ & 2940 & 84 \\
\hline $\begin{array}{l}\text { majmunska posla } \\
\text { 'monkey business' }\end{array}$ & 24900 & 65 \\
\hline $\begin{array}{l}\text { turka štakora } \\
\text { 'rat race' }\end{array}$ & 235 & 18 \\
\hline $\begin{array}{l}\text { otvarač očiju } \\
\text { 'eye opener' }\end{array}$ & 335 & 6 \\
\hline $\begin{array}{l}\text { party životinja } \\
\text { 'party animal' }\end{array}$ & 622 & 3 \\
\hline $\begin{array}{l}\text { majka tigrica } \\
\text { 'tiger mother' }\end{array}$ & 518 & 3 \\
\hline $\begin{array}{l}\text { puževa pošta } \\
\text { 'snail mail' }\end{array}$ & 276 & 3 \\
\hline $\begin{array}{l}\text { garǎnno vino } \\
\text { 'garage wine' }\end{array}$ & 113 & 0 \\
\hline $\begin{array}{l}\text { ljubavni štakor } \\
\text { 'love rat' }\end{array}$ & 4 & 0 \\
\hline
\end{tabular}




\subsection{Instrument}

The research was done by way of an experiment built in PsychoPy, an open-source package for running experiments in Python (Pierce, 2007). The experiment consisted of the following: for each target item 6 statements in Croatian language were designed -3 being true and 3 being false (e.g. Garažno vino je iznimno skupo 'Garage wine is very expensive' [true] vs. Garažno vino je loše kvalitete 'Garage wine is of bad quality' [false]). Each of the statements is an instance of using the target item in context. The experiment was run on a PC. The target sentences $(N=60)$ were presented in white Times New Roman font on a black screen (default setting in PsychoPy), one sentence at a time. Sentences were presented in random order to avoid any possible order effect. At the beginning of the session, instructions appeared on the screen. The participants' task was to press the left arrow key if they considered the sentence to be false or the right arrow key if they considered the sentence to be correct. The programme recorded accuracy (true/false) of the participants' responses, and the reaction times. The participants were not instructed about the length of the experiment and the sentences were presented without any time limit since we were interested in the comprehension of sentences and not the reaction times. Also, sentences were of different length, which would make the reaction times test invalid. Therefore, reaction time was not used as a variable in this experiment.

\subsection{Participants}

The experiment participants were two groups of students: 1) the EXPERIMENTAL GROUP consisted of 21 first-year graduate students of the Faculty of Humanities and Social Sciences in Osijek studying English Language and Literature as their major subject (who have been studying English for three and a half years with about 15 hours of instruction in English per week); 2) the CONTROL GROUP consisted of 21 second-year students of the Faculty of Education in Osijek, who are studying to become class teachers with additional qualification to teach English in early primary education (and have 4 hours and 30 minutes of instruction in English per week). The reason we chose these groups is that we needed two groups with a solid knowledge of English, for two reasons: a. in order to neutralize 'English language proficiency' as a variable ${ }^{4}$, and $b$. because we needed to pre-teach the vocabulary in English (INDEPENDENT VARIABLE). Our choice of groups was also convenient because these are our students, and it was easy to carry out the experiment during our regular classes.

\footnotetext{
${ }^{4}$ Both groups are highly proficient in English as L2. If there are differences, they are not so great as to be relevant for the experiment. What is important though is the fact that the target items are fairly recent and therefore should have been equally unknown to both groups before the start of the experiment.
} 


\subsection{Procedure}

The participants were tested in groups during their regular English classes. Prior to the PsychoPy experiment, the experimental group $(\mathrm{X})$ was pre-taught the 10 target compounds in English, as a part of their Corpus linguistics lesson. In order to teach the students the target noun-noun compounds, a task was devised in which they had to find instances of use of the target items in a corpus (BNC), and based on this make conclusions about their meaning. As a follow-up, the students had to check the meaning of the compounds in available online dictionaries, in order to make sure that they understood the target items correctly. The students were not asked to translate the target compounds, and they were not told of the experiment that would follow. The control group (C) was not pre-taught. The PsychoPy experiment was run a week later (under the assumption that too much time between teaching and testing would lead to forgetting) in a controlled setting using laptops. For the purpose of staying anonymous, the participants were asked to provide a nickname at the beginning of each session. There were no time limits on the decision about the correctness of sentences, which means that the participants could have re-read sentences and thought thoroughly about their meaning - so, the dependent variable was not only 'on-line' and mandatory comprehension, but could have included other, optional and relatively conscious processes such as recognition (Aha, this is from English! or Aha, this is a metaphor!) and interpretation $^{5}$ (conscious construction of meaning, e.g. if you do not know the meaning of garage wine you will probably first interpret it literally as 'a wine kept in a garage', but if you assume it is a metaphor, then different interpretations become possible, such as 'wine which doesn't taste well', 'cheap wine that tastes like diesel', 'a thing with no value', 'an expression which describes something good', 'wine of low quality', 'something old and forgotten', 'a rotten person or car gasoline' $\left.{ }^{6}\right)$. However, the processes of comprehension, recognition, and interpretation may be intertwined and difficult to separate, and since this is not really our focus in this experiment, we will keep referring to comprehension, with the caveat that it may include one or both of the other processes.

\subsection{Scoring}

PsychoPy was programmed to collect the participants' answers (correct/incorrect), and statistical analysis of the correctness of their estimates was performed using IBM SPSS 22 for two subsamples: a) experimental group $X(n=21), b)$ control group $C(n=21)$.

\footnotetext{
${ }^{5}$ Cf. Steen (2007: 350, and passim).

${ }^{6}$ All of these examples were actual interpretations given by participants in a questionnaire (Marinić \& Schmidt, 2017).
} 


\subsection{Analysis and discussion}

Under the assumption that one needs to know the phrase in English in order to understand the meaning of its literal translation (phraseological calque) in Croatian, we hypothesized that pre-taught students (experimental group) will score significantly higher on the decision task.

The participants' answers were categorized as either 'correct' or 'incorrect' and Fisher's exact test (2-sided) was run for each sentence. For the purpose of easier analysis, the results are shown in separate groups of 6 sentences referring to each target item.

\subsubsection{Garažno vino 'garage wine'}

The statistical results for this phrase (Table 4) speak in favour of the hypothesis that knowledge of the conventional meaning of the English template (in this case, garage wine) will increase comprehension of the Croatian calque (in this case, garažno vino) based on that template. For five out of six sentences there was a statistically significant difference (values in bold print, $\mathrm{p} \leq 0.05$ ) between the control and the experimental group, in favour of the experimental group, which indicates that the pre-teaching of the English templates did have a positive effect on the comprehension of the derived Croatian calques.

Since garage wine is not a compound used widely in English, but rather by a limited circle of wine-lovers and wine-producers, it is fair to assume that students were unaware of its meaning prior to pre-teaching and that the experimental group scored significantly higher on the decision task exclusively due to being pretaught the meaning of the English template. The only sentence where there was no statistically significant difference is Garažno vino stoji u garaži 'Garage wine is kept in a garage' (S2) and the reason is probably not the lack of knowledge of experimental group (16 participants answered correctly), but rather the fact that the control group was divided - eleven participants answered that S2 was false and ten answered it was true. This, however, does not indicate that the control group knew the correct meaning of the target phrase. The fact that the responses for this sentence were around 50/50 rather points to guessing.

Table 4. Summary of correct and incorrect answers for the target item garažno vino 'garage wine' on a decision task (Fisher's exact test)

\begin{tabular}{|c|c|c|c|c|c|c|}
\hline Var & Target sentence & ExpA & Part & $\begin{array}{l}\text { Corr } \\
/ 21\end{array}$ & $\begin{array}{l}\text { Incorr } \\
/ 21\end{array}$ & $\mathrm{P}$ \\
\hline \multirow[t]{2}{*}{ S1 } & \multirow{2}{*}{$\begin{array}{l}\text { Garažno vino je loše kvalitete. } \\
\text { 'Garage wine is of bad quali- } \\
\text { ty.' }\end{array}$} & \multirow[b]{2}{*}{$\mathrm{F}$} & $X$ & 17 & 4 & \multirow[b]{2}{*}{.025} \\
\hline & & & C & 9 & 12 & \\
\hline S2 & Garažno vino stoji u garaži. & $\mathrm{F}$ & $x$ & 16 & 5 & .197 \\
\hline
\end{tabular}




\begin{tabular}{|c|c|c|c|c|c|c|}
\hline & $\begin{array}{l}\text { 'Garage wine is kept in a gar- } \\
\text { age.' }\end{array}$ & & C & 11 & 10 & \\
\hline \multirow[t]{2}{*}{ S3 } & \multirow{2}{*}{$\begin{array}{l}\text { Garažno vino je jeftino. } \\
\text { 'Garage wine is cheap.' }\end{array}$} & \multirow{2}{*}{$\mathrm{F}$} & $X$ & 16 & 5 & \multirow{2}{*}{.028} \\
\hline & & & $\mathrm{C}$ & 8 & 13 & \\
\hline \multirow[t]{2}{*}{ S4 } & \multirow{2}{*}{$\begin{array}{l}\text { Garažno vino je visokokvalitetno. } \\
\text { 'Garage wine is of high quali- } \\
\text { ty.' }\end{array}$} & \multirow{2}{*}{$\mathrm{T}$} & $X$ & 16 & 5 & \multirow{2}{*}{.002} \\
\hline & & & C & 5 & 16 & \\
\hline \multirow[t]{2}{*}{ S5 } & \multirow{2}{*}{$\begin{array}{l}\text { Garažno vino je iznimno skupo. } \\
\text { 'Garage wine is extremely } \\
\text { expensive.' }\end{array}$} & \multirow{2}{*}{$\mathrm{T}$} & $X$ & 14 & 7 & \multirow{2}{*}{.004} \\
\hline & & & C & 4 & 17 & \\
\hline \multirow[t]{2}{*}{ S6 } & \multirow{2}{*}{$\begin{array}{l}\text { Garažno se vino proizvodi u } \\
\text { malim količinama. } \\
\text { 'Garage wine is produced in } \\
\text { small quantities.' }\end{array}$} & \multirow{2}{*}{$\mathrm{T}$} & $X$ & 20 & 1 & \multirow{2}{*}{.045} \\
\hline & & & C & 14 & 7 & \\
\hline
\end{tabular}

Note: Var $=$ number of the target sentence, ExpA = expected answer: True $(\mathrm{T})$ or False $(\mathrm{F})$, Part $=$ participants, Corr $=$ number of correct answers, Incorr $=$ number of incorrect answers, $\mathrm{C}=$ control group, $\mathrm{X}=$ experimental group ${ }^{7}$

\subsubsection{Majka tigrica 'tiger mother'}

In the case of majka tigrica, in four target sentences there was a statistically significant difference between the two groups (Table 5). Again in S11, the control group was divided - 10 participants answered that majka tigrica fosters an academically competitive spirit and 11 were on the other side of that idea. The surprising element was S8, which claims that majka tigrica is strong and that she fights for her child. 15 participants from the experimental group answered that this was true, despite the fact that they predominantly answered correctly that tiger mother is strict (S10) and focused on directing her children towards financially successful careers (S12). Probably, this is the influence of the conventional conceptualization of mothers as care-takers and those who fight for the benefit of their children, using various methods. We assume that the meaning of the English source item tiger mother was unknown to the control group; therefore, it is not surprising that 8 participants in that group answered that majka tigrica could be someone's mother who is an attractive woman (S7). Tigrica 'tigress' in Croatian (as well as tiger in English) does have a strong sexual connotation, and the control group, which presumably did not know the original source meaning of this item, most probably drew on their previous knowledge and experiences related to the metaphorically used word tigrica, i.e. an attractive 'tigress' woman, or a mother who fights for her child (like a lion) and is available to her child all the time. Not strict, however, which is the core component of the meaning of this English compound.

\footnotetext{
7 This marking applies to Tables 4 through 13.
} 
Table 5. Summary of correct and incorrect answers for the target item majka tigrica 'tiger mother' on a decision task (Fisher's exact test)

\begin{tabular}{|c|c|c|c|c|c|c|}
\hline Var & Target sentence & ExpA & Part & $\begin{array}{l}\text { Corr } \\
/ 21\end{array}$ & $\begin{array}{l}\text { Incorr } \\
/ 21\end{array}$ & $\mathrm{P}$ \\
\hline \multirow[t]{2}{*}{ S7 } & \multirow{2}{*}{$\begin{array}{l}\text { Majka tigrica je nečija majka, koja } \\
\text { je atraktiona žena. } \\
\text { 'Tiger mother is someone's } \\
\text { mother, who is an attractive } \\
\text { woman.' }\end{array}$} & \multirow[b]{2}{*}{$\mathrm{F}$} & $X$ & 20 & 1 & \multirow[b]{2}{*}{.020} \\
\hline & & & $\mathrm{C}$ & 13 & 8 & \\
\hline \multirow[t]{2}{*}{ S8 } & \multirow{2}{*}{$\begin{array}{l}\text { Majka tigrica je snažna i bori se za } \\
\text { svoje dijete. } \\
\text { 'Tiger mother is strong and she } \\
\text { fights for her child.' }\end{array}$} & \multirow{2}{*}{$\mathrm{F}$} & $X$ & 6 & 15 & \multirow{2}{*}{.093} \\
\hline & & & C & 1 & 20 & \\
\hline \multirow[t]{2}{*}{ S9 } & \multirow{2}{*}{$\begin{array}{l}\text { Majka tigrica je na raspolaganju } \\
\text { djeci cijeli dan. } \\
\text { 'Tiger mother is available to her } \\
\text { children all day.' }\end{array}$} & \multirow[b]{2}{*}{$\mathrm{F}$} & $X$ & 17 & 4 & \multirow[b]{2}{*}{.002} \\
\hline & & & $\mathrm{C}$ & 7 & 14 & \\
\hline \multirow[t]{2}{*}{ S10 } & \multirow{2}{*}{$\begin{array}{l}\text { Majka tigrica je pretjerano stroga } \\
\text { majka. } \\
\text { 'Tiger mother is an extremely } \\
\text { strict mother.' }\end{array}$} & \multirow{2}{*}{$\mathrm{T}$} & $X$ & 16 & 5 & \multirow{2}{*}{.013} \\
\hline & & & $\mathrm{C}$ & 8 & 13 & \\
\hline \multirow[t]{2}{*}{ S11 } & \multirow{2}{*}{$\begin{array}{l}\text { Majka tigrica njeguje natjecateljski } \\
\text { duh u akademskom smislu. } \\
\text { 'Tiger mother fosters an aca- } \\
\text { demically competitive spirit.' }\end{array}$} & \multirow[b]{2}{*}{$\mathrm{T}$} & $X$ & 16 & 5 & \multirow[b]{2}{*}{.111} \\
\hline & & & $\mathrm{C}$ & 10 & 11 & \\
\hline \multirow[t]{2}{*}{ S12 } & \multirow{2}{*}{$\begin{array}{l}\text { Majka tigrica usmjerava djecu } k \\
\text { financijski uspješnoj karijeri. } \\
\text { 'Tiger mother directs her chil- } \\
\text { dren towards financially suc- } \\
\text { cessful careers.' }\end{array}$} & \multirow[b]{2}{*}{$\mathrm{T}$} & $X$ & 18 & 3 & \multirow[b]{2}{*}{.043} \\
\hline & & & $\mathrm{C}$ & 11 & 10 & \\
\hline
\end{tabular}

\subsubsection{Puževa pošta 'snail mail'}

Puževa pošta 'snail mail' is regular mail, as opposed to e-mail. A significant statistical difference between the two groups in three false sentences describing the phrase puževa pošta (Table 6: S13, S14, S15) is an indicator that the knowledge of the meaning of the English template snail mail was helpful to the experimental group. Most of the experimental group answered correctly that puževa pošta does not refer to a type of communication, that it is not mail which you are waiting for a long time, and that it is not a post-office. The majority of the control group answered quite the opposite. However, they guessed that it is old-fashioned, which means that they probably relied on the idea that snails are slow and built a semantic 
frame which is wider in scope than that of the SL item, in which all of the sentences about the item could fit: slow delivery of regular mail through old-fashioned crammed post offices. The experimental group, on the other hand, seem to have been aware of the narrower scope of its meaning.

Table 6. Summary of correct and incorrect answers for the target item puževa pošta 'snail mail' on a decision task (Fisher's exact test)

\begin{tabular}{|c|c|c|c|c|c|c|}
\hline Var & Target sentence & ExpA & Part & Corr & Incorr & $\mathrm{P}$ \\
\hline \multirow[t]{2}{*}{ S13 } & \multirow{2}{*}{$\begin{array}{l}\text { Puževa pošta je slaba komunikacija. } \\
\text { 'Snail mail is weak communica- } \\
\text { tion.' }\end{array}$} & \multirow{2}{*}{$\mathrm{F}$} & $X$ & 17 & 4 & \multirow{2}{*}{.004} \\
\hline & & & C & 7 & 14 & \\
\hline \multirow[t]{2}{*}{ S14 } & \multirow{2}{*}{$\begin{array}{l}\text { Puževa pošta je dugoočekivana } \\
\text { pošta koja nikako da dođe. } \\
\text { 'Snail mail is the long-expected } \\
\text { mail which seems never to ar- } \\
\text { rive.' }\end{array}$} & \multirow[b]{2}{*}{$F$} & $X$ & 15 & 6 & \multirow[b]{2}{*}{.000} \\
\hline & & & $\mathrm{C}$ & 2 & 19 & \\
\hline \multirow[t]{2}{*}{ S15 } & \multirow{2}{*}{$\begin{array}{l}\text { Puževa pošta je pošta u kojoj } \\
\text { radnici sporo rade. } \\
\text { 'Snail mail is a post-office in } \\
\text { which workers are slow.' }\end{array}$} & \multirow{2}{*}{$\mathrm{F}$} & $X$ & 16 & 5 & \multirow{2}{*}{.013} \\
\hline & & & C & 8 & 13 & \\
\hline \multirow[t]{2}{*}{ S16 } & \multirow{2}{*}{$\begin{array}{l}\text { Puževa pošta je obična pošta. } \\
\text { 'Snail mail is regular mail.' }\end{array}$} & \multirow{2}{*}{$\mathrm{T}$} & $X$ & 17 & 4 & \multirow{2}{*}{.052} \\
\hline & & & $\mathrm{C}$ & 10 & 11 & \\
\hline \multirow[t]{2}{*}{ S17 } & \multirow{2}{*}{$\begin{array}{l}\text { Puževa pošta je staromodna. } \\
\text { 'Snail mail is old-fashioned.' }\end{array}$} & \multirow{2}{*}{$\mathrm{T}$} & $X$ & 16 & 5 & \multirow{2}{*}{.697} \\
\hline & & & $\mathrm{C}$ & 18 & 3 & \\
\hline \multirow[t]{2}{*}{ S18 } & \multirow{2}{*}{$\begin{array}{l}\text { Puževom poštom se šalju pisma } i \\
\text { paketi. } \\
\text { 'Snail mail is used to send let- } \\
\text { ters and packages.' }\end{array}$} & \multirow[b]{2}{*}{$\mathrm{T}$} & $X$ & 19 & 2 & \multirow[b]{2}{*}{.067} \\
\hline & & & $\mathrm{C}$ & 13 & 8 & \\
\hline
\end{tabular}

\subsubsection{Party životinja 'party animal'}

The target item party životinja must have been familiar to both groups of participants, since there were no statistically significant differences for any of the 6 statements (Table 7). This is, however, not surprising since in the first part of research by Marinić \& Schmidt (2017) 31 out of 40 participants of different proficiency in English gave a definition corresponding to the original one. This Croatian calque, as found on the web pages we visited, consists of the English word party and the Croatian word životinja 'animal', which does not abide with the rules of Croatian language. There is a word for party in Croatian, and Croatian linguists would probably find this calque quite obnoxious - however, among young population using English words in Croatian is quite usual and the word party signifies that this is a night event, a bit wilder than just hanging out with your friends. The 
word životinja in Croatian, when it refers to humans, evokes a notion of a wild, strong and sturdy person. So, this calque was either familiar to participants or easy to guess, due to already existing, easily combinable semantic frames.

Table 7. Summary of correct and incorrect answers for the target item party životinja 'party animal' on a decision task (Fisher's exact test)

\begin{tabular}{|c|c|c|c|c|c|c|}
\hline Var & Target sentence & ExpA & Part & Corr & Incorr & $\mathrm{P}$ \\
\hline \multirow[t]{2}{*}{ S19 } & Party životinja je energična & \multirow[b]{2}{*}{$F$} & $X$ & 16 & 5 & \multirow[b]{2}{*}{.111} \\
\hline & $\begin{array}{l}\text { 'Party animal is an energetic } \\
\text { animal.' }\end{array}$ & & $\mathrm{C}$ & 10 & 11 & \\
\hline \multirow[t]{2}{*}{ S20 } & $\begin{array}{l}\text { Party životinja je osoba koja se } \\
\text { svojom odjećom razlikuje of dru- }\end{array}$ & \multirow[b]{2}{*}{$F$} & $X$ & 20 & 1 & \multirow[b]{2}{*}{.606} \\
\hline & $\begin{array}{l}\text { 'Party animal is a person who } \\
\text { dresses differently than other } \\
\text { people.' }\end{array}$ & & $\mathrm{C}$ & 18 & 3 & \\
\hline \multirow[t]{2}{*}{ S21 } & \multirow{2}{*}{$\begin{array}{l}\text { Party životinja je izbacivač na } \\
\text { partijima. } \\
\text { 'Party animal is a bouncer at } \\
\text { parties.' }\end{array}$} & \multirow{2}{*}{$\mathrm{F}$} & $X$ & 20 & 1 & \multirow{2}{*}{.606} \\
\hline & & & $\mathrm{C}$ & 18 & 3 & \\
\hline \multirow[t]{2}{*}{ S22 } & \multirow{2}{*}{$\begin{array}{l}\text { Party životinja je osoba koja voli } \\
\text { izlaske. } \\
\text { 'Party animal is a person who } \\
\text { loves to go out.' }\end{array}$} & \multirow{2}{*}{$\mathrm{T}$} & $X$ & 20 & 1 & \multirow{2}{*}{1.000} \\
\hline & & & $\mathrm{C}$ & 19 & 2 & \\
\hline \multirow[t]{2}{*}{ S23 } & \multirow{2}{*}{$\begin{array}{l}\text { Party životinja je osoba koja se } \\
\text { često opija. } \\
\text { 'Party animal is a person who } \\
\text { gets drunk very often.' }\end{array}$} & \multirow{2}{*}{$\mathrm{T}$} & $X$ & 20 & 1 & \multirow{2}{*}{.343} \\
\hline & & & C & 17 & 4 & \\
\hline \multirow[t]{2}{*}{ S24 } & \multirow{2}{*}{$\begin{array}{l}\text { Party životinja je društvena } \\
\text { osoba. } \\
\text { 'Party animal is a sociable } \\
\text { person.' }\end{array}$} & \multirow[b]{2}{*}{$\mathrm{T}$} & $X$ & 18 & 3 & \multirow[b]{2}{*}{.232} \\
\hline & & & C & 21 & 0 & \\
\hline
\end{tabular}

\subsubsection{Poslowni anđeo 'business angel'}

All the participants in the control group answered that poslovni andeo is a person who performs his or her duties well and on time, and most of the participants $(n=19)$ answered that poslovni andeo is someone who is nice to everybody and enjoys his or her work (Table 8). The experimental group gave different answers, with statistically significant differences. Statistically significant was the difference between the two groups in S28 (a person who invests in small businesses - the 
very definition of a business angel), which is a strong indication that the experimental group was aware of its SL meaning, unlike the control group in which 14 participants dismissed this idea. There is no statistically significant difference between the groups for S29 (Business angel provides capital) possibly because a good worker (this is how the control group obviously conceptualized a business angel) also provides capital for his employer.

Table 8. Summary of correct and incorrect answers for the target item poslovni anđeo 'business angel' on a decision task (Fisher's exact test)

\begin{tabular}{|c|c|c|c|c|c|c|}
\hline Var & Target sentence & ExpA & Part & Corr & Incorr & $\mathrm{P}$ \\
\hline \multirow[t]{2}{*}{ S25 } & \multirow{2}{*}{$\begin{array}{l}\text { Poslovni anđeo je osoba koja svoje } \\
\text { obveze obavlja dobro i na vrijeme. } \\
\text { 'Business angel is a person who } \\
\text { does his or her duties well and } \\
\text { on time.' }\end{array}$} & \multirow{2}{*}{$\mathrm{F}$} & $X$ & 15 & 6 & \multirow{2}{*}{.000} \\
\hline & & & $\mathrm{C}$ & 0 & 21 & \\
\hline \multirow[t]{2}{*}{ S26 } & \multirow{2}{*}{$\begin{array}{l}\text { Poslovni anđeo je zgodna poslovna } \\
\text { žena. } \\
\text { 'Business angel is a good- } \\
\text { looking business woman.' }\end{array}$} & \multirow{2}{*}{$\mathrm{F}$} & $X$ & 20 & 1 & \multirow{2}{*}{.093} \\
\hline & & & $\mathrm{C}$ & 15 & 6 & \\
\hline \multirow[t]{2}{*}{ S27 } & \multirow{2}{*}{$\begin{array}{l}\text { Poslovni andeo je netko tko je } \\
\text { dobar prema svima i uživa u ono- } \\
\text { me što radi. } \\
\text { Business angel is someone who } \\
\text { is nice to everybody and enjoys } \\
\text { his/her work. }\end{array}$} & \multirow{2}{*}{$\mathrm{F}$} & $X$ & 16 & 5 & \multirow{2}{*}{.000} \\
\hline & & & $\mathrm{C}$ & 2 & 19 & \\
\hline \multirow[t]{2}{*}{ S28 } & \multirow{2}{*}{$\begin{array}{l}\text { Poslovni anđeo je osoba koja ulaže } \\
\text { u malo poduzetništvo. } \\
\text { 'Business angel is a person who } \\
\text { invests in small businesses.' }\end{array}$} & \multirow{2}{*}{$\mathrm{T}$} & $X$ & 15 & 6 & \multirow{2}{*}{.029} \\
\hline & & & $\mathrm{C}$ & 7 & 14 & \\
\hline \multirow[t]{2}{*}{ S29 } & \multirow{2}{*}{$\begin{array}{l}\text { Poslovni anđeo osigurava kapital. } \\
\text { 'Business angel provides capi- } \\
\text { tal.' }\end{array}$} & \multirow{2}{*}{$\mathrm{T}$} & $X$ & 19 & 2 & \multirow{2}{*}{.663} \\
\hline & & & C & 17 & 4 & \\
\hline \multirow[t]{2}{*}{ S30 } & $\begin{array}{l}\text { Poslovni anđeo često ima udio u } \\
\text { vlasništvu. }\end{array}$ & \multirow{2}{*}{$\mathrm{T}$} & $X$ & 14 & 7 & \multirow{2}{*}{.350} \\
\hline & $\begin{array}{l}\text { 'Business angel often has a } \\
\text { share in the ownership.' }\end{array}$ & & $\mathrm{C}$ & 10 & 11 & \\
\hline
\end{tabular}

\subsubsection{Otvarač očiju 'eye opener'}

For the control group, otvarač očiju can as easily be an eye-lid (S32), as well as a person (S33) who is a realist telling others the truth (Table 9). However, these two sentences are the only ones with a statistically significant difference. The other 
sentences show that both groups think that eye-opener is not something pointless or impossible, but rather something surprising, shocking and enlightening. Again, we have a situation where the control group, although assumedly not aware of the source phrase meaning, manages to fit in these definitions into a wider semantic frame, possibly due to the Croatian metaphorical expression otvoriti oči 'to open your eyes', meaning 'to make you see or realize something you did not know before'. In Croatian, both a person and an event or situation can open your eyes to something. So, relying on this, the control group was able to give a lot of correct answers. However, the most prominent agent in case of the English expression eye opener is not a person (S33), which the experimental group correctly answered (with a statistically significant difference in relation to the control group). Also, the control group allowed the possibility of this item being a metonymy (S32: 15 participants answered it was a word meaning an eye-lid).

Table 9. Summary of correct and incorrect answers for the target item otvarač očiju 'eye opener' on a decision task (Fisher's exact test)

\begin{tabular}{|c|c|c|c|c|c|c|}
\hline Var & Target sentence & ExpA & Part & Corr & Incorr & $\mathrm{P}$ \\
\hline \multirow[t]{2}{*}{ S31 } & \multirow{2}{*}{$\begin{array}{l}\text { Otvarač očiju je nešto besmisleno ili } \\
\text { nemoguće. } \\
\text { 'Eye opener is something pointless or } \\
\text { impossible.' }\end{array}$} & \multirow[b]{2}{*}{$\mathrm{F}$} & $X$ & 16 & 5 & \multirow[b]{2}{*}{1.000} \\
\hline & & & $\mathrm{C}$ & 16 & 5 & \\
\hline \multirow[t]{2}{*}{ S32 } & \multirow{2}{*}{$\begin{array}{l}\text { Otvarač očiju je kapak. } \\
\text { 'Eye opener is an eye-lid.' }\end{array}$} & \multirow{2}{*}{$\mathrm{F}$} & $X$ & 18 & 3 & \multirow{2}{*}{.000} \\
\hline & & & C & 6 & 15 & \\
\hline \multirow[t]{2}{*}{ S33 } & \multirow{2}{*}{$\begin{array}{l}\text { Otvarač očiju je realist koji govori ljudi- } \\
\text { ma istinu. } \\
\text { 'Eye opener is a realist who tells peo- } \\
\text { ple the truth.' }\end{array}$} & \multirow[b]{2}{*}{$\mathrm{F}$} & $X$ & 14 & 7 & \multirow[b]{2}{*}{.004} \\
\hline & & & C & 4 & 17 & \\
\hline \multirow[t]{2}{*}{ S34 } & \multirow{2}{*}{$\begin{array}{l}\text { Otvarač očiju je vrsta iznenađenja. } \\
\text { 'Eye opener is a kind of surprise.' }\end{array}$} & \multirow{2}{*}{$\mathrm{T}$} & $X$ & 15 & 6 & \multirow{2}{*}{.208} \\
\hline & & & $\mathrm{C}$ & 10 & 11 & \\
\hline \multirow[t]{2}{*}{ S35 } & \multirow{2}{*}{$\begin{array}{l}\text { Otvarač očiju je poučan. } \\
\text { 'Eye opener is enlightening.' }\end{array}$} & \multirow{2}{*}{$\mathrm{T}$} & $X$ & 16 & 5 & \multirow{2}{*}{.734} \\
\hline & & & C & 14 & 7 & \\
\hline \multirow[t]{2}{*}{ S36 } & \multirow{2}{*}{$\begin{array}{l}\text { Otvarač očiju je iznenadno ili šokatno } \\
\text { otkriće. } \\
\text { 'Eye opener is a sudden or shocking } \\
\text { discovery.' }\end{array}$} & \multirow[b]{2}{*}{$\mathrm{T}$} & $X$ & 16 & 5 & \multirow[b]{2}{*}{.505} \\
\hline & & & C & 13 & 8 & \\
\hline
\end{tabular}

\subsubsection{Ljubavni štakor 'love rat'}

Love rat is an unfaithful (cheating) and promiscuous partner. The control group was divided on the sentences referring to these senses of ljubavni štakor (Table 10: S40-S42) -- in each case 11 participants answered they were false, 10 answered they 
were true. On the other hand, the experimental group was predominantly confident of their correctness, which indicates that knowing the source phrase love rat did help them understand the calque ljubavni štakor. Most participants in the experimental group gave correct answers for all sentences (from 16 participants in S40 to 18 participants in S38, S41 and S42). However, a statistically significant difference did not appear in all the sentences because of the indecisive nature of the control group's answers (S40) and the control group's correct ideas about the meaning of ljubavni štakor (which did not include a person who is romantic (S39), a rat which is in love (S37), nor someone who recounts incorrect information (S38)). In this research, however, we are not interested so much in details of their conceptualization of the target calque (for this see Marinić \& Schmidt, 2017), but rather whether their conceptualization matches the conventional meaning (dictionary definition) of the SL template.

Table 10. Summary of correct and incorrect answers for the target item ljubavni štakor 'love rat' on a decision task (Fisher's exact test)

\begin{tabular}{|c|c|c|c|c|c|c|}
\hline Var & Target sentence & ExpA & Part & Corr & Incorr & $\mathrm{P}$ \\
\hline \multirow[t]{2}{*}{ S37 } & \multirow{2}{*}{$\begin{array}{l}\text { Ljubavni štakor je štakor koji voli. } \\
\text { 'Love rat is a rat which is in } \\
\text { love.' }\end{array}$} & \multirow{2}{*}{$\mathrm{F}$} & $X$ & 17 & 4 & \multirow{2}{*}{.306} \\
\hline & & & C & 13 & 8 & \\
\hline \multirow[t]{2}{*}{ S38 } & \multirow{2}{*}{$\begin{array}{l}\text { Ljubavni štakor je onaj koji prenosi } \\
\text { krive informacije. } \\
\text { 'Love rat is the one who re- } \\
\text { counts incorrect information.' }\end{array}$} & \multirow{2}{*}{$\mathrm{F}$} & $X$ & 18 & 3 & \multirow{2}{*}{.697} \\
\hline & & & C & 16 & 5 & \\
\hline \multirow[t]{2}{*}{ S39 } & \multirow{2}{*}{$\begin{array}{l}\text { Ljubavni štakor je romantična oso- } \\
b a . \\
\text { 'Love rat is a romantic person.' }\end{array}$} & \multirow{2}{*}{$\mathrm{F}$} & $X$ & 17 & 4 & \multirow{2}{*}{.719} \\
\hline & & & $\mathrm{C}$ & 15 & 6 & \\
\hline \multirow[t]{2}{*}{ S40 } & \multirow{2}{*}{$\begin{array}{l}\text { Ljubavni štakor je osoba koja vara } \\
\text { partnera. } \\
\text { 'Love rat is a person who cheats } \\
\text { on his/her partner.' }\end{array}$} & \multirow{2}{*}{$\mathrm{T}$} & $X$ & 16 & 5 & \multirow{2}{*}{.111} \\
\hline & & & C & 10 & 11 & \\
\hline \multirow[t]{2}{*}{ S41 } & \multirow{2}{*}{$\begin{array}{l}\text { Ljubavni štakor je nevjeran. } \\
\text { 'Love rat is unfaithful.' }\end{array}$} & \multirow{2}{*}{$\mathrm{T}$} & $X$ & 18 & 3 & \multirow{2}{*}{.020} \\
\hline & & & $\mathrm{C}$ & 10 & 11 & \\
\hline \multirow[t]{2}{*}{ S42 } & \multirow{2}{*}{$\begin{array}{l}\text { Ljubavni štakor je promiskuitetan. } \\
\text { 'Love rat is promiscuous.' }\end{array}$} & \multirow{2}{*}{$\mathrm{T}$} & $X$ & 18 & 3 & \multirow{2}{*}{.020} \\
\hline & & & $\mathrm{C}$ & 10 & 11 & \\
\hline
\end{tabular}

\subsubsection{Majmunska posla 'monkey business'}

A statistically significant difference between the two groups appeared in only one sentence (Table 11: S44). To answer why, we need to start from the obvious - even the true sentences which describe the main components of the meaning of monkey 
business in English ((S46) and (S47), referring to 'mischievous and deceitful behaviour' are very often not accepted by the experimental group. Taking into account that this expression in Croatian, although literally translated from English, has existed in Croatian longer than other tested items (Marinić \& Schmidt, 2017), and has in the meantime acquired somewhat different meaning - of something that an idle person does, mainly things which are not important or serious and sometimes even unacceptable, like fooling around, for instance (Marinić, 2015: 164-168). The results show that even the pre-taught participants (experimental group) could not separate the meaning of this phrase in English and Croatian - 13 pre-taught participants answered that monkey business means banal and undemanding things (S43), and 12 did not mark them as dishonest (S47). These results indicate that preteaching of the SL template for an already familiar calque could not influence its established conceptualization (at least not significantly).

Table 11. Summary of correct and incorrect answers for the target item majmunska posla 'monkey business' on a decision task (Fisher's exact test)

\begin{tabular}{|c|c|c|c|c|c|c|}
\hline Var & Target sentence & ExpA & Part & Corr & Incorr & $\mathrm{P}$ \\
\hline \multirow[t]{2}{*}{ S43 } & \multirow{2}{*}{$\begin{array}{l}\text { Majmunska posla su banalne } i \\
\text { nezahtjevne stvari. } \\
\text { 'Monkey business are banal } \\
\text { and undemanding things.' }\end{array}$} & \multirow[b]{2}{*}{$\mathrm{F}$} & $X$ & 8 & 13 & \multirow[b]{2}{*}{.744} \\
\hline & & & C & 6 & 15 & \\
\hline \multirow[t]{2}{*}{ S44 } & \multirow{2}{*}{$\begin{array}{l}\text { Majmunska posla znače zabadati } \\
\text { nos gdje mu nije mjesto. } \\
\text { 'Monkey business means stick- } \\
\text { ing your nose where it does not } \\
\text { belong.' }\end{array}$} & \multirow[b]{2}{*}{$\mathrm{F}$} & $X$ & 20 & 1 & \multirow[b]{2}{*}{.020} \\
\hline & & & C & 13 & 8 & \\
\hline \multirow[t]{2}{*}{ S45 } & \multirow{2}{*}{$\begin{array}{l}\text { Majmunska posla su poslovi koje } \\
\text { bi i majmuni mogli obavljati. } \\
\text { 'Monkey bussines are things } \\
\text { that even monkeys could do.' }\end{array}$} & \multirow{2}{*}{$\mathrm{F}$} & $X$ & 18 & 3 & \multirow{2}{*}{.159} \\
\hline & & & C & 13 & 8 & \\
\hline \multirow[t]{2}{*}{ S46 } & \multirow{2}{*}{$\begin{array}{l}\text { Majmunska posla služe obman- } \\
\text { jivanju ljudi. } \\
\text { 'Monkey business serves to } \\
\text { deceive people.' }\end{array}$} & \multirow[b]{2}{*}{$\mathrm{T}$} & $X$ & 11 & 10 & \multirow[b]{2}{*}{1.000} \\
\hline & & & C & 11 & 10 & \\
\hline \multirow[t]{2}{*}{ S47 } & \multirow{2}{*}{$\begin{array}{l}\text { Majmunska posla su nepoštena. } \\
\text { 'Monkey business is dishonest.' }\end{array}$} & \multirow{2}{*}{$\mathrm{T}$} & $X$ & 9 & 12 & \multirow{2}{*}{.215} \\
\hline & & & C & 14 & 7 & \\
\hline \multirow[t]{2}{*}{ S48 } & \multirow{2}{*}{$\begin{array}{l}\text { Majmunska posla su } \\
\text { neprihvatlivo ponašanje. } \\
\text { 'Monkey business is unac- } \\
\text { ceptable behaviour.' }\end{array}$} & \multirow{2}{*}{$\mathrm{T}$} & $X$ & 15 & 6 & \multirow{2}{*}{.208} \\
\hline & & & C & 10 & 11 & \\
\hline
\end{tabular}




\subsubsection{Utrka štakora 'rat race'}

There were three sentences (S50, S51, S54) with a statistically significant difference in understanding of the meaning of this calque (Table 12). Most of the experimental group answered correctly that it was not the race of equals (S50), or a betting race of rats (S51), and that it was a competition between people (S54). The other, statistically insignificant differences are a result of a wider semantic frame created by the participants for the understanding of the calque, a frame which includes rats, people, and betting. For instance, 12 participants in the control group answered correctly that rat race was exhausting (S52) and that is was a way of life (S53), but these ideas fit easily into this wider frame. We take the results of S50, S51 and especially S54 as an indicator that the experimental group knew the meaning of $u$ trka štakora due to the pre-teaching of the English expression rat race.

Table 12. Summary of correct and incorrect answers for the target item utrka štakora 'rat race' on a decision task (Fisher's exact test)

\begin{tabular}{|c|c|c|c|c|c|c|}
\hline Var & Target sentence & ExpA & Part & Corr & Incorr & $\mathrm{P}$ \\
\hline \multirow{2}{*}{ S49 } & \multirow{2}{*}{$\begin{array}{l}\text { Utrka štakora je brza utrka. } \\
\text { 'Rat race is a fast race.' }\end{array}$} & \multirow[b]{2}{*}{$\mathrm{F}$} & $X$ & 15 & 6 & \multirow{2}{*}{.118} \\
\hline & & & $C$ & 9 & 12 & \\
\hline \multirow[t]{2}{*}{ S50 } & \multirow{2}{*}{$\begin{array}{l}\text { Utrka štakora je utrka jednakih. } \\
\text { 'Rat race is a race of equals.' }\end{array}$} & \multirow{2}{*}{$\mathrm{F}$} & $X$ & 15 & 6 & \multirow{2}{*}{.013} \\
\hline & & & $\mathrm{C}$ & 6 & 15 & \\
\hline \multirow[t]{2}{*}{ S51 } & \multirow{2}{*}{$\begin{array}{l}\text { U utrci štakora štakori trče u krug, } \\
\text { a ljudi se klade na pobjednika. } \\
\text { 'Rat race is a race in which rats } \\
\text { run in circles, and people bet on } \\
\text { the winning rat.' }\end{array}$} & \multirow{2}{*}{ F } & $X$ & 19 & 2 & \multirow{2}{*}{.015} \\
\hline & & & C & 11 & 10 & \\
\hline \multirow[t]{2}{*}{ S52 } & \multirow{2}{*}{$\begin{array}{l}\text { Utrka štakora je iscrpljujuća. } \\
\text { 'Rat race is exhausting.' }\end{array}$} & \multirow{2}{*}{$\mathrm{T}$} & $X$ & 16 & 5 & \multirow{2}{*}{.326} \\
\hline & & & $C$ & 12 & 9 & \\
\hline \multirow[t]{2}{*}{ S53 } & \multirow{2}{*}{$\begin{array}{l}\text { Utrka štakora je način života. } \\
\text { 'Rat race is a way of life.' }\end{array}$} & \multirow{2}{*}{$\mathrm{T}$} & $x$ & 10 & 11 & \multirow{2}{*}{.758} \\
\hline & & & $\mathrm{C}$ & 12 & 9 & \\
\hline \multirow[t]{2}{*}{ S54 } & \multirow{2}{*}{$\begin{array}{l}\text { U utrci štakora ljudi se natječu. } \\
\text { 'Rat race is a race in which peo- } \\
\text { ple compete.' }\end{array}$} & \multirow{2}{*}{$\mathrm{T}$} & $x$ & 18 & 3 & \multirow{2}{*}{.020} \\
\hline & & & C & 10 & 11 & \\
\hline
\end{tabular}

\subsubsection{Stakleni strop 'glass ceiling'}

Although there was the same number of sentences with statistically significant vs. insignificant differences between groups (Table 13), again one thing is obvious the components of meaning which are crucial to the understanding of the phrase stakleni strop, modelled on an English template glass ceiling (its discriminatory nature (S59) and its negative effect on the advancement of women's careers (S58)) seem not to have been understood by the control group and to have been under- 
stood by the experimental group. Also, for half of the control group this could be an expression for something beautiful (S57), although the numbers point to guessing. Other results are ambiguous and it is possible that the sentences were not chosen too carefully; e.g. (S60) Stakleni strop nitko ne priznaje 'Glass ceiling is not acknowledged' could be interpreted either as true or false - if this term exists and people talk about this phenomenon, it is kind of acknowledged (but not widely or openly, in which case we may see the sentence as true). However, sentences S57, S58 and S59 are possibly proof enough that the experimental group understood the calque better, due to the knowledge of the English template.

Table 13. Summary of correct and incorrect answers for the target item stakleni strop 'glass ceiling' on a decision task (Fisher's exact test)

\begin{tabular}{|c|c|c|c|c|c|c|}
\hline Var & Target sentence & ExpA & Part & Corr & Incorr & $\mathrm{P}$ \\
\hline \multirow[t]{2}{*}{ S55 } & $\begin{array}{l}\text { Stakleni strop je izraz za prepreku } \\
\text { u odrastanju. }\end{array}$ & \multirow{2}{*}{$F$} & $X$ & 13 & 8 & \multirow{2}{*}{.536} \\
\hline & $\begin{array}{l}\text { 'Glass ceiling is an expression } \\
\text { for an obstacle in growing up.' }\end{array}$ & & $\mathrm{C}$ & 10 & 11 & \\
\hline \multirow[t]{2}{*}{ S56 } & Stakleni strop je prozirna laž. & \multirow{2}{*}{$\mathrm{F}$} & $X$ & 14 & 7 & \multirow{2}{*}{1.000} \\
\hline & 'Glass ceiling is an obvious lie.' & & $\mathrm{C}$ & 13 & 8 & \\
\hline \multirow[t]{2}{*}{ S57 } & $\begin{array}{l}\text { Stakleni strop je izraz za nešto } \\
\text { divno, kao pogled na nebo. }\end{array}$ & \multirow[b]{2}{*}{$\mathrm{F}$} & $X$ & 18 & 3 & \multirow[b]{2}{*}{.020} \\
\hline & $\begin{array}{l}\text { 'Glass ceiling is an expression } \\
\text { for something beautiful, such as } \\
\text { looking at the sky.' }\end{array}$ & & $\mathrm{C}$ & 10 & 11 & \\
\hline \multirow[t]{2}{*}{ S58 } & Stakleni strop sprječava napredak. & \multirow{2}{*}{$\mathrm{T}$} & $X$ & 17 & 4 & \multirow{2}{*}{.001} \\
\hline & advancement.' & & C & 5 & 16 & \\
\hline \multirow[t]{2}{*}{ S59 } & Stakleni strop diskriminira. & \multirow{2}{*}{$\mathrm{T}$} & $X$ & 16 & 5 & \multirow{2}{*}{.012} \\
\hline & 'Glass ceiling discriminates.' & & $\mathrm{C}$ & 7 & 14 & \\
\hline \multirow[t]{2}{*}{ S60 } & Stakleni strop nitko ne priznaje. & \multirow[b]{2}{*}{$\mathrm{T}$} & $X$ & 11 & 10 & \multirow[b]{2}{*}{.208} \\
\hline & $\begin{array}{l}\text { 'Glass ceiling is not acknowl- } \\
\text { edged.' }\end{array}$ & & $\mathrm{C}$ & 6 & 15 & \\
\hline
\end{tabular}

\section{Comparison with prior research}

To compare this with the results of the previous research, where none of the participants were pre-taught, see Table 14. Basically, there is a statistically significant difference between the two groups of participants with different proficiency in English (C1 vs. B2 ${ }^{8}$ ) for items party životinja 'party animal', poslovni anđeo 'business

${ }^{8}$ According to CEFR (Council of Europe 2001). 
angel', utrka štakora 'rat race' and stakleni strop 'glass ceiling'. However, if we look only at the number of participants who gave a correct definition of each item (column Corr) we can see that the only calque where C1 students considerably outperformed B2 students is utrka štakora 'rat race' (30 out of $40 \mathrm{C} 1$ students gave a correct definition, while only four B2 students did the same). Comparing this with the results of the present research, we might conclude that the pre-teaching of English expressions did positively influence the understanding of the Croatian calques based on them; much more so than the level of English language proficiency.

Table 14. Comparison of participants' corresponding (Corr) and non-corresponding (NonCorr) definitions given by B2 and C1 students (Fisher's Exact Test) (Marinić \& Schmidt, 2017)

\begin{tabular}{|c|c|c|c|c|c|}
\hline Target item & $\begin{array}{l}\text { Participants } \\
\text { B2 students }(n=40) \\
\text { C1 students }(n=40)\end{array}$ & $\begin{array}{c}\text { Missing } \\
\text { Values }\end{array}$ & Corr & NonCorr & $\mathrm{P}$ \\
\hline \multirow[t]{2}{*}{ garažno vino } & B2 & 1 & 1 & 38 & \multirow{2}{*}{ 172 } \\
\hline & $\mathrm{C} 1$ & 7 & 4 & 29 & \\
\hline \multirow[t]{2}{*}{ majka tigrica } & B2 & 0 & 17 & 23 & \multirow{2}{*}{821} \\
\hline & $\mathrm{C} 1$ & 2 & 15 & 23 & \\
\hline \multirow[t]{2}{*}{ puževa pošta } & B2 & 1 & 9 & 30 & \multirow{2}{*}{,136 } \\
\hline & $\mathrm{C} 1$ & 4 & 15 & 21 & \\
\hline \multirow[t]{2}{*}{ party životinja } & B2 & 1 & 31 & 8 & \multirow{2}{*}{,014 } \\
\hline & $\mathrm{C} 1$ & 0 & 39 & 1 & \\
\hline \multirow[t]{2}{*}{ poslovni andeo } & B2 & 0 & 3 & 37 & \multirow{2}{*}{,030 } \\
\hline & $\mathrm{C} 1$ & 7 & 9 & 24 & \\
\hline \multirow[t]{2}{*}{ otvarač očiju } & B2 & 0 & 18 & 22 & \multirow{2}{*}{,074 } \\
\hline & $\mathrm{C} 1$ & 2 & 25 & 13 & \\
\hline \multirow[t]{2}{*}{ ljubavni štakor } & B2 & 0 & 3 & 37 & \multirow{2}{*}{ 638 } \\
\hline & $\mathrm{C} 1$ & 12 & 1 & 27 & \\
\hline \multirow[t]{2}{*}{ majmunska posla } & B2 & 0 & 6 & 34 & \multirow{2}{*}{,770 } \\
\hline & $\mathrm{C} 1$ & 1 & 7 & 32 & \\
\hline \multirow[t]{2}{*}{ utrka štakora } & B2 & 2 & 4 & 34 & \multirow{2}{*}{,000 } \\
\hline & $\mathrm{C} 1$ & 3 & 30 & 7 & \\
\hline \multirow[t]{2}{*}{ stakleni strop } & B2 & 1 & 3 & 36 & \multirow{2}{*}{,003 } \\
\hline & $\mathrm{C} 1$ & 9 & 12 & 19 & \\
\hline
\end{tabular}

\section{Constraints of the present research}

Not to jump to conclusions, it must be repeated that some of the sentences provided in the present experiment seem to be a bit ambiguous, and also in some cases it was possible to give a correct answer even if the meaning of the item was not fully 
understood. In some cases, the control group managed to fit these definitions into wider semantic frames invoked for the purpose of understanding the calques. However, some sentences expressed details that referred to very specific meaning components, crucial to the correct understanding of the target items. Often these crucial meaning components were not recognised by the control group, and statistically significant differences between groups appeared in those very examples. The test sentences were designed using participants' answers from the previous research (Marinić \& Schmidt, 2017), which led to difficulties in the analysis of the results. Designing non-ambiguous definitional sentences would have been a better way towards crystal clear results, however there are certain benefits of this approach, as well. For instance, the fact that 15 participants in the control group missed the metaphorical meaning of 'eye opener' and said that it was an eye-lid, or that 'snail mail' is a post-office building, would probably not be discovered using definitional sentences only. Also, in case of the definitional sentences (and without other sentences which reflect certain nuances in the meaning of the target items), we would not be able to decide whether participants actually knew that some definition was true/false or simply guessed so. If we compare the results in Table 15 (where there are only those test sentences which could be described as definitional) to the discussion of individual examples, particularly 'snail mail', 'eye opener', 'love rat' and 'rat race', we see that the fact that there is no statistically significant difference between control group and experimental group on definitional sentences does not necessarily mean that control group knows the meaning of the target item.

Table 15. Summary of correct and incorrect answers for the definitions of target items on a decision task (Fisher's exact test)

\begin{tabular}{|c|c|c|c|c|c|c|}
\hline Var & Target sentence & ExpA & Part & Corr & Incorr & $\mathrm{P}$ \\
\hline \multirow[t]{2}{*}{ S4 } & \multirow{2}{*}{$\begin{array}{l}\text { 'Garage wine is of high } \\
\text { quality.' }\end{array}$} & \multirow{2}{*}{$\mathrm{T}$} & $X$ & 16 & 5 & \multirow{2}{*}{.002} \\
\hline & & & $\mathrm{C}$ & 5 & 16 & \\
\hline \multirow[t]{2}{*}{ S10 } & \multirow{2}{*}{$\begin{array}{l}\text { 'Tiger mother is an ex- } \\
\text { tremely strict mother.' }\end{array}$} & \multirow{2}{*}{$\mathrm{T}$} & $X$ & 16 & 5 & \multirow{2}{*}{.013} \\
\hline & & & $\mathrm{C}$ & 8 & 13 & \\
\hline \multirow[t]{2}{*}{ S18 } & \multirow{2}{*}{$\begin{array}{l}\text { 'Snail mail is used to } \\
\text { send letters and packag- } \\
\text { es.' }\end{array}$} & \multirow{2}{*}{$\mathrm{T}$} & $X$ & 19 & 2 & \multirow{2}{*}{.067} \\
\hline & & & C & 13 & 8 & \\
\hline \multirow[t]{2}{*}{ S22 } & \multirow{2}{*}{$\begin{array}{l}\text { 'Party animal is a person } \\
\text { who loves to go out.' }\end{array}$} & \multirow{2}{*}{$\mathrm{T}$} & $X$ & 20 & 1 & \multirow{2}{*}{1.000} \\
\hline & & & $\mathrm{C}$ & 19 & 2 & \\
\hline \multirow[t]{2}{*}{ S28 } & \multirow{2}{*}{$\begin{array}{l}\text { 'Business angel is a per- } \\
\text { son who invests in small } \\
\text { businesses.' }\end{array}$} & \multirow{2}{*}{$\mathrm{T}$} & $X$ & 15 & 6 & \multirow{2}{*}{.029} \\
\hline & & & $\mathrm{C}$ & 7 & 14 & \\
\hline \multirow[t]{2}{*}{ S36 } & \multirow{2}{*}{$\begin{array}{l}\text { 'Eye opener is a sudden } \\
\text { or shocking discovery.' }\end{array}$} & \multirow{2}{*}{$\mathrm{T}$} & $X$ & 16 & 5 & \multirow{2}{*}{.505} \\
\hline & & & $\mathrm{C}$ & 13 & 8 & \\
\hline
\end{tabular}




\begin{tabular}{|c|l|c|r|r|r|r|}
\hline S40 & \multirow{2}{*}{$\begin{array}{c}\text { 'Love rat is a person } \\
\text { who cheats on his/her } \\
\text { partner.' }\end{array}$} & $\mathrm{T}$ & $\mathrm{X}$ & 16 & 5 & \multirow{2}{*}{.111} \\
\cline { 4 - 6 } & & $\mathrm{C}$ & 10 & 11 & \\
\hline S46 & $\begin{array}{c}\text { 'Monkey business serves } \\
\text { to deceive people.' }\end{array}$ & $\mathrm{T}$ & $\mathrm{X}$ & 11 & 10 & \multirow{2}{*}{1.000} \\
\cline { 4 - 6 } S53 & 'Rat race is a way of life.' & \multirow{2}{*}{$\mathrm{T}$} & $\mathrm{C}$ & 11 & 10 & \multirow{2}{*}{.758} \\
\cline { 4 - 6 } & & & $\mathrm{C}$ & 12 & 9 & \\
\hline S58 & $\begin{array}{l}\text { 'Glass ceiling is a barrier } \\
\text { to advancement.' }\end{array}$ & \multirow{2}{*}{$\mathrm{T}$} & $\mathrm{X}$ & 17 & 4 & \multirow{2}{*}{.001} \\
\cline { 4 - 6 } & & $\mathrm{C}$ & 5 & 16 & 11 & \\
\hline
\end{tabular}

Another debatable issue is the fact that the experimental group was not told about the testing that would follow (which could have motivated them to memorize the English items better). However, the type of task they were given is usually done in this lesson, and students are tested regularly, so they are already motivated to remember the newly acquired vocabulary. Also, if we look at this from a different angle, we might say that this makes the research results even more credible. Namely, after only one exposure to the meaning of the source language items, the experimental group was able to score better than the control group. The experimental group was also slightly more proficient in English than the other group (C1 vs. B2), but even the most proficient speakers of English as a second language are very often not acquainted with the meaning of idioms or in this case quite rare metaphorical noun-noun compounds. Besides, previous research has shown that C1 students, compared to B2 students, were considerably better at defining only one of the calques used in this research (Marinić \& Schmidt, 2017).

\section{Conclusion}

We started this research from the assumption, based on previous research (Pavičić Takač et al, 2015; Marinić \& Schmidt, 2017), that in order to fully comprehend certain phraseological calques it is not enough to be proficient in the source language; one also has to know the conventional meaning of the SL template. In this case knowing the conventional meaning of the English template is a quite specific part of English language proficiency, because we considered fairly recent or less known expressions. In this research we tested the hypothesis that knowledge of the conventional meaning of the English metaphorical compounds will increase comprehension of the Croatian calques appearing in Croatian online sources, which are based on these English templates. Generally speaking, pre-taught students (the experimental group) were more successful on the decision task in 55 out of 60 sentences. However, a statistically significant difference was observed for 26 sentences. At first, this seemed discouraging for our hypothesis. But, the analysis of individual sentences (or certain groups of sentences) strongly indicates that the pre- 
taught participants (experimental group) did understand the calques more precisely than the control group. The control group participants, who were not aware of the meaning of the English templates (at least we assumed so) managed to fit in some of their guesses about the meaning of the calques into a wider semantic frame, and quite often guessed the correct answer, but when it came to the core components of the meaning (e.g. majka tigrica 'tiger mother' as a strict, demanding mother; or stakleni strop 'glass ceiling' as a barrier to advancement, etc.) they were very often wrong, unlike the experimental group participants, who gave mostly the correct answers about these essential meaning components. Taking all of the above into consideration, we think that there are strong indications that our hypothesis is not false. In other words, it seems that indeed knowing the SL template increases comprehension of the TL calque based on that template.

The implications of this research could be of special interest to persons involved in designing media texts, professional and student translators, as well as to mass media consumers. Translators have to be aware that phraseological calques are often understandable only to people who already know the meaning of the source language template. Moreover, in the case of metaphorical calques it is possible that people with no knowledge of the source language (templates) will construe the meaning of the calque differently than intended by the source-language users. If a translator or a journalist still decides to use a phraseological calque of the type used in this research, the calque would need to be precisely defined, particularly if it is new or recent, if misunderstanding is to be avoided.

\section{References}

Aixelá, Javier Franco (1996). Culture-specific items in translation. Álvarez, Román, María Carmen-África Vidal, eds. Translation, Power, Subversion. Clevedon: Multilingual Matters, 52-79.

Anić, Vladimir (2004). Rječnik hrvatskoga jezika. (4th edn.). Zagreb: Novi Liber.

Benczes, Réka (2006). Creative Compounding in English: The Semantics of Metaphorical and Metonymical Noun-Noun Combinations. Amsterdam - Philadelphia: John Benjamins.

Biber, Douglas, Stig Johansson, Geoffrey Leech, Susan Conrad, Edward Finegan (1999). The Longman Grammar of Spoken and Written English. London: Longman.

Bujas, Željko (1999). English-Croatian Dictionary. Zagreb: Nakladni zavod Globus.

Coulson, Seana, Todd Oakley (2000). Blending basics. Cognitive Linguistics 11.3-4: 175-196.

Davies, Mark (2008-) The Corpus of Contemporary American English: 520 Million Words, 1990Present. Available online at http://corpus.byu.edu/coca/.

Fauconnier, Gilles, Mark Turner (1998). Conceptual integration networks. Cognitive Science 22.2: 133-187.

Fauconnier, Gilles, Mark Turner (2002). The Way We Think: Conceptual Blending and the Mind's Hidden Complexities. New York: Basic Books.

Filipović, Rudolf et al. (1999). English-Croatian Dictionary. (24th edn.). Zagreb: Školska knjiga. 
Fillmore, Charles J. (1982). Frame semantics. The Linguistic Society of Korea, ed. Linguistics of the Morning Calm, Selected Papers from SICOL-1981. Seoul: Hanshin, 111-137.

Haspelmath, Martin, Uri Tadmor (2009). Loanwords in the world's languages: a comparative handbook. New York, N.Y.: De Gruyter Mouton.

Hrvatski jezični portal (2016). Available online at http://hjp.znanje.hr/.

Langacker, Ronald W. (1987). Foundations of Cognitive Grammar: Theoretical Prerequisites. Volume 1. Stanford: Stanford University Press.

Marinić, Ivana (2015). Konstrukcija i konceptualizacija u višejezičnom umu (Construction and Conceptualisation in the Multilingual Mind). Osijek: Filozofski fakultet Osijek. (Doctoral dissertation.)

Marinić, Ivana, Goran Schmidt (2017). Can a tigress change her stripes? On the comprehension of metaphor-based phraseological calques. Baicchi, Annalisa, \& Erica Pinelli, eds. Conceptual Modeling in Language and Discourse across Cultures. Newcastle upon Tyne: Cambridge Scholars Publishing, 153-170.

Oxford Dictionaries Online (2016). Available online at http://www.oxford dictionaries.com/.

Pavičić Takač, Višnja, Gabrijela Buljan, Romana Čačija (2015). Croatian and English in contact: „Evribadi spiks ingliš“, but do we understand Croatian? Cergol Kovačević, Kristina, Sanda Lucija Udier, eds. Multidisciplinary Approaches to Multilingualism. Proceedings from the CALS Conference 2014. Frankfurt am Main: Peter Lang, 51-74.

Pavlović, Nataša (2015). Uvod u teorije prevođenja. Zagreb: Leykam International.

Peirce, Jonathan W. (2007). PsychoPy - Psychophysics software in Python. Journal of Neuroscience Methods 162.1-2: 8-13.

Quirk, Randolph, Sidney Greenbaum, Geoffrey Leech, Jan Svartvik (1985). A Comprehensive Grammar of the English Language. London: Longman.

Steen, Gerard J. (2007). Finding Metaphor in Grammar and Usage. Amsterdam: John Benjamins.

Tadić, Marko (2009). New version of the Croatian National Corpus. Hlaváčková, Dana, Aleš Horák, Klara Osolsobě, Pavel Rychlý, eds. After Half a Century of Slavonic Natural Language Processing. Brno: Masaryk University, 199-205.

Turk, Marija (2003). Razumljivost i stilističke značajke kalkova. Fluminensia 15.1: 9-24.

Turk, Marija (2013). Jezično kalkiranje u teoriji i praksi: Prilog lingvistici jezičnih dodira. Zagreb: Hrvatska sveučilišna naklada, Filozofski fakultet Sveučilišta u Rijeci.

Turner, Mark (2007). Conceptual integration. Geeraerts, Dirk, Hubert Cuckyens, eds. The Oxford Handbook of Cognitive Linguistics. Oxford: Oxford University Press, 377-393.

Turner, Mark, Gilles Fauconnier (1995). Conceptual integration and formal expression. Metaphor and Symbolic Activity 10.3: 183-204.

Turner, Mark, Gilles Fauconnier (2000). Metaphor, metonymy, and binding. Barcelona, Antonio, ed. Metonymy and Metaphor. Berlin - New York: Walter de Gruyter, 133145.

UrbanDictionary.com (1996-2016). Available online at http://www.urbandictionary.com/.

Authors' addresses:

Goran Schmidt

J.J. Strossmayer University in Osijek

Faculty of Humanities and Social Sciences

Department of English Language and Literature 
Lorenza Jägera 9, 31000 Osijek, Croatia

E-mail: gschmidt@ffos.hr

Ivana Marinić

J.J. Strossmayer University in Osijek

Faculty of Education,

Department of Philology

Cara Hadrijana 10, 31000 Osijek, Croatia

E-mail: imarinic@foozos.hr

Received: April 9, 2017

Accepted for publication: May 17, 2017 